times more susceptible to cleavage by $\gamma$-radiation ${ }^{8}(G 2 \cdot 4)$. It is clear that protection by aromatic groups, as described here, offers a useful practical method of reducing the radiation lability of carbohydrates and demonstrates that facile energy transfer is possible in these molecules.

Department of Chemistry,

$$
\text { GIJYN O. PHILLIPS * }
$$

University College, Cardiff.

Florine A. Blouin

Jett C. Arthur, Jun.

Southern Regional Research Laboratory,

Agricultural Research Service,

United States Department of Agriculture,

New Orleans, Louisiana.

* Rescarch Chemist, Southern Regional Research Laboratory, Julyseptember 1963.

' Wolfrom, M. L., Binkley, W. W., and MeCabe, L. J., J. Amer. Chem. Soc. $81,1442(1959)$

"Phillips, G. O., and Moody, G. J., J. Chem. Soc., 762 (1960).

${ }^{3}$ Foster, A. B., and Overend, W. G., Chem. and Indust., 566 (1955).

- Isbell, H. S., and Frush, H. I., U.S. Bur. Stand. J. Res., 24, 125 (1940)

'Somogyi, M., J. Biol. Chem., 195, 19 (1952).

"Chapiro, A., Radiation Chemistry of Polymeric Systems, 344 (Interscience Publishers, New York, 1962).

Burton, M., Disc. Faraday Soc., No. 33, 7 (1963).

' Phillips, G. O., Adv. Carbohydrate Chem., 16, 13 (1961).

\section{Pyrolysis of Chlorodifluoromethane and the Heat of Formation of Chlorodifluoromethane and Difluoromethylene}

IN a recent communication by Gozzo and Patrick ${ }^{1}$ the heat of formation of difluoromethylene was estimated at $\leqslant-43 \mathrm{keal} / \mathrm{mole}$ from an investigation of the kinetics of pyrolysis of chlorodifluoromethane. We completed a similar investigation of this pyrolysis in the range $530^{\circ}-$ $700^{\circ} \mathrm{C}$ some time ago and obtained slightly different results (to be submitted for publication elsewhere). We believe that the main reaction steps are as follows:

$$
\begin{aligned}
& \mathrm{CF}_{2} \mathrm{HCl} \rightarrow \mathrm{CF}_{2}+\mathrm{HCl} \\
& \mathrm{CF}_{2}+\mathrm{HCl} \rightarrow \mathrm{CF}_{2} \mathrm{HCl} \\
& 2 \mathrm{CF}_{2} \rightarrow \mathrm{C}_{2} \mathrm{~F}_{4} \\
& \mathrm{C}_{2} \mathrm{~F}_{4} \rightarrow 2 \mathrm{CF}_{2}
\end{aligned}
$$

The inhibiting effect of $\mathrm{HCl}$ (that is, reaction 2) was confirmed by copyrolysis of $\mathrm{CF}_{2} \mathrm{HCl}$ and $\mathrm{HCl}$. Further, pyrolysis of a mixture of $\mathrm{CF}_{2} \mathrm{HCl}$ with $\mathrm{HBr}$ led to $\mathrm{CF}_{2} \mathrm{HBr}$ as the main product. Reaction 4 was inferred from the reversibility of the overall reaction:

$$
2 \mathrm{CF}_{2} \mathrm{HCl}_{2} \rightleftharpoons \mathrm{C}_{2} \mathrm{~F}_{4}+2 \mathrm{HCl}
$$

The function $p\left(\mathrm{C}_{2} \mathrm{~F}_{4}\right) p^{2}(\mathrm{HCl}) / p^{2}\left(\mathrm{CF}_{2} \mathrm{HCl}\right)$ has the form of an equilibrium constant, and in static system investigations at $600^{\circ} \mathrm{C}$ this function was found to increase with time and attain a maximum value, after which it fell slowly because of the formation of side products. It was possible to extrapolate the curve and make an estimate of what the final value of the function would have been had there been no side reactions. A value of $8.7 \times 10^{-2} \mathrm{~atm}$. was obtained. Published thermodynamic data ${ }^{2,3}$ lead to a value of $30.1 \mathrm{cal} / \mathrm{mole} \operatorname{deg}$ for $\Delta S^{\circ}$ for reaction (5) and hence to a value of $30.5 \mathrm{kcal} / \mathrm{mole}$ for $\Delta H^{\circ}$, at $600^{\circ} \mathrm{C}$, which corresponds to $\Delta H^{\circ}=29.1 \mathrm{kcal} / \mathrm{mole}$ at $25^{\circ} \mathrm{C}$. If the heat of formation of tetrafluoroethylene is taken as $-151.5 \mathrm{kcal} / \mathrm{mole}$, this leads to a value of $-112.3 \mathrm{kcal} /$ mole for the heat of formation of chlorodifluoromethane at $25^{\circ} \mathrm{C}$, which is close to several recent estimates ${ }^{1,4-6}$.

Arrhenius parameters were obtained for reactions 1, 2, 3 and 4 by using a computer to integrate the kinetic equations and to obtain a least-squares fit to the experimental results obtained in a flow system at 1 atm. over the range $530^{\circ}-700^{\circ} \mathrm{C}$. Use was made of available thermodynamic data, including the heat of reaction (5) estimated as indicated, to minimize the number of independent parameters to be found, and $E_{3}$ was assumed to be zero. An empirical expression was used to take account of the formation of by-products (which have been described by Park ${ }^{7}$ ); the amount formed rarely exceeded a fow per cent.

The Arrhenius parameters found in the least-squares procedure mentioned were (in kcal, litre, mole, sec units) $A_{1}=10^{13.84}, A_{2}=10^{8.35}, A_{3}=10^{9.94}, A_{4}=10^{16.66}, E_{1}=55.8$ $E_{2}=6 \cdot 2, E_{3}=0$ (assumed), $E_{4}=70 \cdot 4$. From these data, a value of $-39.1 \mathrm{kcal} / \mathrm{mole}$ for the heat of formation of $\mathrm{CF}_{2}$ at $25^{\circ} \mathrm{C}$ is obtained; this is in reasonable agreement with various recent estimates ${ }^{1,4}$.

When $E_{3}$ was introduced as a further adjustable parameter into the least-squares fitting instead of being assumed zero, a value of about $5.8 \mathrm{kcal} / \mathrm{mole}$ was obtained. but this was very badly determined and did not exceed its own uncertainty. The corresponding heat of formation of $\mathrm{CF}_{2}$ was $-46 \cdot 3 \mathrm{kcal} / \mathrm{mole}$.

We thank Mr. I. Gray and Mr. J. G. P. Barnes of Imperial Chemical Industries Central Instrument Laboratory for computing assistance.

J. W. Fowards

P. A. SMat.

Research Department,

Imperial Chemical Industries Ltd.

(Plastics Division),

Welwyn Garden City.

${ }^{1}$ Gozzo, F., and Patrick, C. R., Nature, 202, 80 (1964).

${ }^{2}$ Weissman, Herman B., Meister, Arnold G., and Cleveland, forrest F., J. Chem. Phys., 28, 72 (1958).

${ }^{3}$ Mann, D. E., Acquista, Nicolo, and Plyler, Earle K., J. Res. Nat. Tzur. Stand., 52, 67 (1954).

‘ JANAF" Thermochemical Data (Dow Chemical Co., 1961).

${ }^{5}$ Masiov, P. G., and Maslov, Yu. P., Chem. Abs., 53, 1910 h (1959).

' Skuratov, S. M., and Kolesov, V. P., Zh. fiz. Khim., 35, 1156 (1961).

Park, J. D., Benning, A. F., Downing, F. B., Laucius, J. F., and McHarness, R. C., Indust. Eng. Chem., 39, 354 (1947).

\section{Inhibition of Corrosion of Iron in Chromic Acid}

Corrosion of iron is completely inhibited in $0.1 \mathrm{~N}$ chromic acid of $p \mathrm{H} 1 \cdot 4$, but a loss of $4000 \mathrm{mg} / \mathrm{dm}^{2}$ was recorded on iron in $0.1 \mathrm{~N}$ sulphuric acid of $p \mathrm{H} 1.6$ after immersion for 4 weeks. Film thickness and time-potential measurements indicated the oxide film on iron to be more protectivo in chromic acid than sulphuric acid.

The electrode potential of iron in chromic acid after $24 \mathrm{~h}$ fluctuates from +0.4 to $+0.5 \mathrm{~V}$ (hydrogen scale), while that in sulphuric acid after $24 \mathrm{~h}$ is $-0 \cdot 36 \mathrm{~V}$.

The oxide film thickness inereases from $12 \AA$ to $22 \cdot 5 \AA$ after $24 \mathrm{~h}$ in chromic acid, but decreases from $6 \AA$ to values $\leqslant 5 \AA$ after $24 \mathrm{~h}$ in sulphuric acid. Contact of bulk $\alpha-\mathrm{Fe}_{2} \mathrm{O}_{3}$ and $\mathrm{Fe}_{3} \mathrm{O}_{4}$ with the acids for $\mathrm{l} \mathrm{h}$ caused the dissolution of 0.5 p.p.m. of iron from $\alpha-\mathrm{Fe}_{2} \mathrm{O}_{3}$ and 13 p.p.m. of iron from $\mathrm{Fe}_{3} \mathrm{O}_{4}$ in each acid. A.fter $24 \mathrm{~h}$ the corresponding figures were 7 and 100 p.p.m. respectively in chromic acid, and 9 and 50 p.p.m. in sulphuric acid.

Measurement of the rate of solution of iron from oxidecovered iron showed 0.7 p.p.m. of iron dissolved from $90 \mathrm{~cm}^{2}$ of iron in $200 \mathrm{ml}$. of chromic acid solution after $1 \mathrm{~h}$. while 15 p.p.m. dissolved in sulphurie acid. Contact of iron powder with chromic acid produced chromic ion: 0.5 p.p.m. of chromium was irreversibly absorbed from $200 \mathrm{ml}$. of chromic acid on to $90 \mathrm{~cm}^{2}$ of iron after immersion for $1 \mathrm{~h}$.

The electrochemistry of iron was investigated in chromic and sulphuric acids using a potentiostat (Fig. 1). After reduction of the oxide film on iron by application of a cathodic current of $40 \mathrm{~m}$.amp $/ \mathrm{cm}^{2}$ for $2 \mathrm{~min}-7.5 \mathrm{mc} . \mathrm{cm}^{2}$ is required to reduce the oxide film on iron ${ }^{1}$ - the potential of the iron electrodo was increased, readings being taken at 2 -min intervals. Results obtained in sulphuric acid showed no evidence of film formation involving ferrous oxide formation until an anodic current of $24 \mathrm{~m} \cdot \mathrm{amp} / \mathrm{cm}^{2}$ 